\title{
Influence of apocynin on cardiac remodeling in rats with streptozotocin-induced diabetes mellitus
}

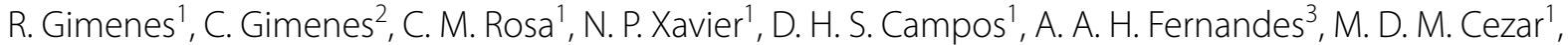 \\ G. N. Guirado', L. U. Pagan' ${ }^{1}$, I. D. Chaer ${ }^{1}$, D. C. Fernandes ${ }^{4}$, F. R. Laurindo ${ }^{4}$, A. C. Cicogna' , M. P. Okoshi ${ }^{1}$ \\ and K. Okoshi ${ }^{1,5^{*}}$
}

\begin{abstract}
Background: Increased reactive oxygen species (ROS) generation in diabetes mellitus (DM) is an important mechanism leading to diabetic cardiomyopathy. Apocynin, a drug isolated from the herb Picrorhiza kurroa, is considered an antioxidant agent by inhibiting NADPH oxidase activity and improving ROS scavenging. This study analyzed the influence of apocynin on cardiac remodeling in diabetic rats.

Methods: Six-month-old male Wistar rats were assigned into 4 groups: control $(C T L, n=15)$, control + apocynin $(C T L+A P O, n=20)$, diabetes $(D M, n=20)$, and diabetes + apocynin $(D M+A P O, n=20)$. DM was induced by streptozotocin. Seven days later, apocynin $(16 \mathrm{mg} / \mathrm{kg} /$ day) or vehicle was initiated and maintained for 8 weeks. Left ventricular (LV) histological sections were used to analyze interstitial collagen fraction. NADPH oxidase activity was evaluated in LV samples. Comparisons between groups were performed by ANOVA for a $2 \times 2$ factorial design followed by the Bonferroni post hoc test.

Results: Body weight (BW) was lower and glycemia higher in diabetic animals. Echocardiogram showed increased left atrial diameter, LV diastolic diameter, and LV mass indexed by BW in both diabetic groups; apocynin did not affect these indices. LV systolic function was impaired in DM groups and unchanged by apocynin. Isovolumic relaxation time was increased in DM groups; transmitral E/A ratio was higher in DM + APO compared to DM. Myocardial functional evaluation through papillary muscle preparations showed impaired contractile and relaxation function in both DM groups at baseline conditions. After positive inotropic stimulation, developed tension (DT) was lower in DM than CTL. In DM + APO, DT had values between those in DM and CTL + APO and did not significantly differ from either group. Myocardial interstitial collagen fraction was higher in DM than CTL and did not differ between DM + APO and CTL + APO. Serum activity of antioxidant enzymes glutathione peroxidase, superoxide dismutase (SOD), and catalase was lower in DM than CTL; apocynin restored catalase and SOD levels in DM + APO. Myocardial NADPH oxidase activity did not differ between groups.
\end{abstract}

Conclusion: Apocynin restores serum antioxidant enzyme activity despite unchanged myocardial NADPH oxidase activity in diabetic rats.

Keywords: Diabetic cardiomyopathy, Heart failure, Oxidative stress, NADPH oxidase, NADPH oxidase blocker, Echocardiogram, Papillary muscle, Rat, Ventricular function, Myocardial function

\footnotetext{
*Correspondence: katashi@fmb.unesp.br

${ }^{5}$ Departamento de Clinica Medica, Faculdade de Medicina de Botucatu,

Sao Paulo State University, UNESP, Rubiao Junior, S/N, Botucatu, SP CEP

18618-687, Brazil

Full list of author information is available at the end of the article
} 


\section{Background}

Diabetes mellitus (DM) is considered an epidemic disease causing great challenge to public health all over the world. Aging, urbanization, and an unhealthy lifestyle such as inadequate diet and sedentarism are mainly responsible for its increased incidence [1]. Diabetesinduced hyperglycemia is related to damage in several organs and associated with vascular and cardiac diseases such as arterial hypertension, coronary artery disease, and heart failure, which are responsible for increased morbidity and mortality [2].

Diabetes-associated changes in myocardial structure and function, unrelated to coronary artery disease, arterial hypertension, valvular heart disease, or congenital heart disease, are called diabetic cardiomyopathy [3]. Several mechanisms are involved in diabetic cardiomyopathy including metabolic changes, myocyte hypertrophy, myocardial interstitial fibrosis, apoptosis, microvascular disease, autonomic dysfunction, energy production deterioration, intracellular calcium homeostasis alterations, and myocardial contractile proteins impairment [3-5]. Increase in reactive oxygen species (ROS) production caused by DM-induced metabolic changes is considered a major factor in triggering myocardial changes [6-8].

The nicotinamide adenine dinucleotide phosphate (NADPH) oxidase family is an important source of ROS in the cardiovascular system. NADPH oxidase activity is increased in cardiomyocytes and endothelial cells during cardiac hypertrophy induced by pressure overload contributing to ROS production and contractile dysfunction [9-11]. Studies in diabetic animals have shown elevated NADPH oxidase activity in the ventricular myocardium associated with cardiomyocyte hypertrophy and apoptosis, myocardial collagen deposition, and contractile dysfunction [12-15].

Apocynin, a drug isolated from the medicinal herb Picrorhiza kurroa [16], is considered an antioxidant agent which inhibits NADPH oxidase activity and improves ROS scavenging [17-19]. We have previously observed that apocynin reduces myocardial oxidative stress without changing NADPH oxidase activity in diabetic hypertensive rats [20]. Although beneficial effects of apocynin have been described in cardiac remodeling [11, 21-24], its cardiac effects have been poorly addressed in diabetic cardiomyopathy $[13,15,25]$. In this study, we investigated the influence of apocynin on cardiac remodeling in normotensive rats with streptozotocin-induced DM.

\section{Materials and methods}

\section{Experimental groups}

Six-month-old male Wistar rats were divided into four groups: control (CTL, $\mathrm{n}=15$ ); control treated with apocynin (CTL + APO, $\mathrm{n}=20)$; diabetes $(\mathrm{DM}, \mathrm{n}=20)$; and diabetes treated with apocynin $(\mathrm{DM}+\mathrm{APO}, \mathrm{n}=20)$. All animals were housed in a room under temperature control at $23{ }^{\circ} \mathrm{C}$ and kept on a 12-h light/dark cycle. Commercial chow and water were supplied ad libitum.

Diabetes was induced by intraperitoneal injection of streptozotocin (Sigma, St. Louis, MO, USA) at $50 \mathrm{mg} / \mathrm{kg}$ body weight diluted in $0.01 \mathrm{M}$ citrate buffer $\mathrm{pH} 4.5$ [26, 27]. Control groups received an intraperitoneal injection of vehicle only. Seven days after streptozotocin administration, blood glucose was measured by glucometer $\left(\right.$ Advantage $^{\circledR}$ ). Only rats with glycemia $>220 \mathrm{mg} / \mathrm{dL}$ were considered diabetic and included in the study [28]. Apocynin (Sigma, St. Louis, MO, USA) was added to drinking water at a dosage of $16 \mathrm{mg} / \mathrm{kg} /$ day for 8 weeks [20, 29]. Systolic blood pressure was measured at the end of experiment by the tail-cuff method using an electrosphygmomanometer (Narco Bio-System ${ }^{\circledR}$, International Biomedical Inc., USA) [30]. All rats underwent environment adaption before tail-cuff measurements.

\section{Echocardiographic study}

Echocardiographic evaluation was performed at the end of the experimental period. We used a commercially available echocardiograph (General Electric Medical Systems, Vivid S6, Tirat Carmel, Israel) equipped with a $5-11.5 \mathrm{MHz}$ multifrequency probe, as previously described [31-34]. Rats were anesthetized by intraperitoneal injection of a mixture of ketamine $(50 \mathrm{mg} / \mathrm{kg})$ and xylazine $(0.5 \mathrm{mg} / \mathrm{kg})$. Two-dimensionally guided M-mode images were obtained from short-axis views of the left ventricle (LV) just below the tip of the mitral-valve leaflets, and at the level of the aortic valve and left atrium. All LV structures were measured by the same observer (KO) and according to the leading-edge method of the American Society of Echocardiography [35]. Values obtained were the mean of at least five cardiac cycles on $\mathrm{M}$-mode tracings. The following structural variables were measured: left atrial diameter (LA), LV diastolic (LVDD) and systolic (LVSD) diameter, and LV diastolic posterior wall thickness (PWT). LV mass was calculated using the formula $\left[(\mathrm{LVDD}+\mathrm{PWT}+\mathrm{SWT})^{3}-(\mathrm{LVDD})^{3}\right] \times 1.04$. $^{3}$ LV function was assessed by the following parameters: endocardial fractional shortening (EFS), ejection fraction (EF), posterior wall shortening velocity (PWSV), tissue Doppler imaging (TDI) of mitral annulus systolic velocity $\left(S^{\prime}\right)$, early and late diastolic mitral inflow velocities ( $\mathrm{E}$ and $\mathrm{A}$ waves), $\mathrm{E} / \mathrm{A}$ ratio, isovolumic relaxation time (IVRT), TDI of early mitral annulus diastolic velocity $\left(\mathrm{E}^{\prime}\right)$, and $E / E^{\prime}$ ratio. Tissue Doppler variables $\left(S^{\prime}\right.$ and $\left.E^{\prime}\right)$ were measured at the septal and lateral walls, and average values presented [36,37]. 


\section{Myocardial functional evaluation}

At the end of the experimental period, myocardial contractile performance was evaluated in isolated LV papillary muscle preparation as previously described [38-40]. Rats were anesthetized (pentobarbital sodium, $50 \mathrm{mg} /$ $\mathrm{kg}$, intraperitoneally) and decapitated. Hearts were quickly removed and placed in oxygenated Krebs-Henseleit solution at $28{ }^{\circ} \mathrm{C}$. LV anterior or posterior papillary muscle was dissected free, mounted between two spring clips, and placed vertically in a chamber containing Krebs-Henseleit solution at $28^{\circ} \mathrm{C}$ and oxygenated with a mixture of $95 \% \mathrm{O}_{2}$ and $5 \% \mathrm{CO}_{2}(\mathrm{pH} 7.38)$. The composition of the Krebs-Henseleit solution in $\mathrm{mM}$ was as follows: $118.5 \mathrm{NaCl}, 4.69 \mathrm{KCl}, 1.25 \mathrm{CaCl}_{2}, 1.16 \mathrm{MgSO}_{4}, 1.18$ $\mathrm{KH}_{2} \mathrm{PO}_{4}, 5.50$ glucose, and $25.88 \mathrm{NaHCO}_{3}$. The spring clips were attached to a Kyowa model 120T-20B force transducer and a lever system which allowed for muscle length adjustment. Preparations were stimulated 12 times/min at a voltage $10 \%$ above threshold.

After a 60 min period, during which the preparations were permitted to shorten while carrying light loads, muscles were loaded to contract isometrically and stretched to the point where active tension development reached its maximum. After a 5 min period, during which preparations performed isotonic contractions, muscles were again placed under isometric conditions, and the peak of the length-tension curve $\left(\mathrm{L}_{\max }\right)$ was determined. A $15 \mathrm{~min}$ period of stable isometric contraction was imposed prior to the experimental period. One isometric contraction was then recorded for later analysis.

The following parameters were measured from the isometric contraction: peak of developed tension (DT), resting tension (RT), time to peak tension (TPT), maximum rate of tension development $(+\mathrm{dT} / \mathrm{dt})$, and maximum rate of tension decline $(-\mathrm{dT} / \mathrm{dt})$. To evaluate myocardial contractile reserve, papillary muscle mechanical performance was evaluated after the following positive inotropic stimuli: $30 \mathrm{~s}$ post-rest contraction, extracellular $\mathrm{Ca}^{2+}$ concentration increase to $2.5 \mathrm{mM}$, and $\beta$-adrenergic agonist isoproterenol $\left(10^{-6} \mathrm{M}\right)$ added to the nutrient solution $[41,42]$. Papillary muscle cross-sectional area (CSA) was calculated from muscle weight and length by assuming cylindrical uniformity and a specific gravity of 1.0. All force data were normalized for muscle CSA.

\section{Histologic analysis}

Transverse LV sections were fixed in $10 \%$ buffered formalin and embedded in paraffin. Sections ( $5 \mu \mathrm{m}$ thick) were stained with hematoxylin-eosin and collagen-specific stain picrosirius red (Sirius red F3BA in aqueous saturated picric acid) [43]. The smallest transverse diameters were measured in at least 50 myocytes from each $\mathrm{LV}$, where the nucleus could be clearly identified [44].
On average, 20 microscopic fields were used to quantify interstitial collagen fraction. Perivascular collagen was excluded from this analysis [45]. Measurements were performed using a Leica microscope (magnification $40 \times$ ) attached to a video camera and connected to a computer equipped with image analysis software (Image-Pro Plus 3.0, Media Cybernetics, Silver Spring, MD, USA).

\section{Plasma glucose and oxidative stress}

After anesthesia and before heart removal from the chest, rats were decapitated and blood collected. Plasma was separated by centrifugation and used for quantification of glucose, glutathione peroxidase (GSH-Px), superoxide dismutase (SOD), and catalase.

Glutathione peroxidase (GSH-Px, E.C.1.11.1.9) activity was assayed in $15 \mu \mathrm{L}$ of serum using $0.15 \mathrm{M}$ phosphate buffer, $\mathrm{pH}$ 7.0, containing $5 \mathrm{mM}$ EDTA, $0.1 \mathrm{~mL}$ of $0.0084 \mathrm{M}$ NADPH, $4 \mu \mathrm{g}$ of GSSG-reductase, $1.125 \mathrm{M}$ sodium azide, and $0.15 \mathrm{M}$ glutathione reduced form in a total volume of $0.3 \mathrm{~mL}$ [32]. Superoxide dismutase (SOD, E.C.1.15.1.1.) activity was determined in serum aliquots of $50 \mu \mathrm{L}$ using its ability to inhibit reduction of nitroblue tetrazolium, in medium containing $50 \mathrm{mM}$ phosphate buffer $\mathrm{pH}$ 7.4, $0.1 \mathrm{mM}$ EDTA, $50 \mu \mathrm{M}$ NBT, $78 \mu \mathrm{M} \mathrm{NADH}$, and $3.3 \mu \mathrm{M}$ phenazine methosulfate. One unit of superoxide dismutase was defined as the amount of protein needed to decrease the reference rate to $50 \%$ of maximum inhibition [28]. Catalase (E.C.1.11.1.6.) activity was evaluated in $50 \mathrm{mM}$ phosphate buffer, $\mathrm{pH} 7.0$, with $10 \mathrm{mM}$ hydrogen peroxide. One unit of catalase was defined as the amount of enzyme needed to degrade $1 \mu \mathrm{mol} \mathrm{H}_{2} \mathrm{O}_{2}$ over $60 \mathrm{~s}$, at $240 \mathrm{~nm}$. Enzyme activity was analyzed at $25{ }^{\circ} \mathrm{C}$ using a microplate reader system ( $\mu$ Quant-MQX 200 with KC Junior software, Bio-TeK Instruments, Winooski, VT, USA). All reagents were purchased from Sigma (St. Louis, MO, USA).

\section{Myocardial NADPH oxidase activity}

NADPH oxidase activity was evaluated in membraneenriched cellular fraction by quantifying two dihydroethidium (DHE) oxidation-derived fluorescent compounds, 2-hydroxyethidium (EOH) and ethidium, by HPLC according to a previously described method [46, 47]. After washing cardiac tissue in phosphate buffered saline, muscle fragments $(\sim 200 \mathrm{mg})$ were homogenized in $1 \mathrm{~mL}$ of ice-cold lysis buffer containing $50 \mathrm{mM}$ Tris ( $\mathrm{pH}$ 7.4), $100 \mathrm{mM}$ DTPA, 0.1\% $\beta$-mercaptoethanol, and protease inhibitors. The samples were sonicated (3 cycles of $10 \mathrm{~s}$ at $8 \mathrm{~W}$ ) and centrifuged at $1000 \mathrm{~g}$ for $3 \mathrm{~min}$, at $4{ }^{\circ} \mathrm{C}$. The supernatant was transferred to another microtube and centrifuged at $18,000 \mathrm{~g}$ for $10 \mathrm{~min}$ at $4{ }^{\circ} \mathrm{C}$. The supernatant was then centrifuged at $100,000 \mathrm{~g}$ for $45 \mathrm{~min}$, at $4{ }^{\circ} \mathrm{C}$. The pellet was resuspended in $100 \mu \mathrm{L}$ of lysis buffer. Total 
protein content was quantified by the Bradford method. Subsequently, $20 \mu \mathrm{g}$ of membrane-enriched cellular fraction was incubated in phosphate buffer $(50 \mathrm{mM}, \mathrm{pH}$ 7.4, with $0.1 \mathrm{mM}$ DTPA) containing DHE $(50 \mu \mathrm{M})$ and $\mathrm{NADPH}(300 \mu \mathrm{M})$ to a final volume of $100 \mu \mathrm{L}$, for $30 \mathrm{~min}$ at $37{ }^{\circ} \mathrm{C}$ in the dark. After adding $40 \mu \mathrm{L}$ of $10 \%$ trichloroacetic acid, the samples were ice-cooled for $10 \mathrm{~min}$ in the dark, and centrifuged at $12,000 \mathrm{~g}$ for $10 \mathrm{~min}$ at $4{ }^{\circ} \mathrm{C}$. The supernatant was analyzed by HPLC and the fluorescent DHE-derived products were quantified.

\section{Statistical analysis}

Results are expressed as mean and standard deviation or median and 25th and 75th percentiles according to normal or non-normal distribution, respectively. Variables were compared by analysis of variance (ANOVA) for a $2 \times 2$ factorial design followed by the Bonferroni post hoc test. Comparisons of interest: CTL + APO vs CTL, $\mathrm{DM}$ vs $\mathrm{CTL}$, and $\mathrm{DM}+\mathrm{APO}$ vs both $\mathrm{CTL}+\mathrm{APO}$ and DM. Statistical significance was accepted at $\mathrm{p}<0.05$.

\section{Results}

During the experimental period, 2 rats from CTL, 1 from $\mathrm{CTL}+\mathrm{APO}, 2$ from DM, and 3 from DM + APO groups died. One rat from DM and 1 from DM + APO did not have hyperglycemia and were excluded from the study. Initial and final body weights (BW) and systolic arterial pressure (SAP) are presented in Table 1. Initial BW did not differ between groups. Final BW was lower and SAP was higher in diabetic groups compared with their respective controls. Apocynin did not change BW or SAP.

Table 2 shows echocardiographic structural data. As body weight significantly differed between groups, cardiac dimensions were normalized to its value to compensate for changes in body mass [48]. LVDD, LAD, and LVM indexed for BW were higher in diabetic groups compared to their respective controls. LV posterior wall thickness was lower in diabetics than controls. LVSD did not statistically differ between groups. Apocynin did not change cardiac structural data. Echocardiographic

Table 1 Body weight and systolic arterial pressure

\begin{tabular}{lllll}
\hline & $\begin{array}{l}\text { CTL } \\
(\mathbf{n}=13)\end{array}$ & $\begin{array}{l}\text { CTL + APO } \\
(\mathbf{n}=19)\end{array}$ & $\begin{array}{l}\text { DM } \\
(\mathbf{n}=17)\end{array}$ & $\begin{array}{l}\text { DM + APO } \\
(\mathbf{n}=16)\end{array}$ \\
\hline Initial BW (g) & $460(447-503)$ & $461(442-493)$ & $467(443-498)$ & $469(443-490)$ \\
Final BW (g) & $543 \pm 53$ & $519 \pm 52$ & $316 \pm 43^{*}$ & $313 \pm 44^{\#}$ \\
SAP (mmHg) & $118 \pm 10$ & $114 \pm 12$ & $129 \pm 13^{*}$ & $131 \pm 15^{\#}$ \\
\hline
\end{tabular}

Data are expressed as mean \pm standard deviation or median and 25 th and 75 th percentiles

$C T L$ control, $C T L+A P O$ control treated with apocynin, DM diabetes mellitus, $D M+A P O$ diabetes mellitus treated with apocynin, $B W$ body weight, $S A P$ systolic arterial pressure

${ }^{*} \mathrm{p}<0.05$ vs $\mathrm{CTL}$; ${ }^{\#} \mathrm{p}<0.05$ vs CTL + APO
Table 2 Echocardiographic structural data

\begin{tabular}{lllll}
\hline & $\begin{array}{l}\text { CTL } \\
(\mathbf{n}=13)\end{array}$ & $\begin{array}{l}\text { CTL + APO } \\
(\mathbf{n}=19)\end{array}$ & $\begin{array}{l}\text { DM } \\
(\mathbf{n}=17)\end{array}$ & $\begin{array}{l}\text { DM + APO } \\
(\mathbf{n}=16)\end{array}$ \\
\hline $\mathrm{LVDD}(\mathrm{mm})$ & $8.39 \pm 0.62$ & $8.24 \pm 0.49$ & $8.03 \pm 0.51$ & $7.82 \pm 0.65^{\#}$ \\
$\mathrm{LVSD}(\mathrm{mm})$ & $3.92 \pm 0.48$ & $3.87 \pm 0.62$ & $4.11 \pm 0.62$ & $4.16 \pm 0.58$ \\
$\mathrm{LVDD} / \mathrm{BW}(\mathrm{mm} /$ & $15.6 \pm 2.15$ & $16.0 \pm 1.74$ & $25.7 \pm 2.87^{*}$ & $25.3 \pm 3.13^{\#}$ \\
$\mathrm{~kg})$ & & & & \\
$\mathrm{PWT}(\mathrm{mm})$ & $1.47 \pm 0.07$ & $1.47 \pm 0.07$ & $1.37 \pm 0.08^{*}$ & $1.32 \pm 0.08^{\#}$ \\
$\mathrm{LA}(\mathrm{mm})$ & $5.76 \pm 0.95$ & $5.92 \pm 0.63$ & $5.68 \pm 0.77$ & $5.35 \pm 0.81^{\#}$ \\
$\mathrm{LA} / \mathrm{BW}(\mathrm{mm} / \mathrm{kg})$ & $10.8 \pm 2.35$ & $11.6 \pm 1.91$ & $18.1 \pm 2.35^{*}$ & $17.3 \pm 3.03^{\#}$ \\
$\mathrm{LVM} / \mathrm{BW}(\mathrm{g} / \mathrm{kg})$ & $1.68 \pm 0.27$ & $1.71 \pm 0.26$ & $2.44 \pm 0.32^{*}$ & $2.25 \pm 0.32^{\#}$ \\
\hline
\end{tabular}

Data are expressed as mean \pm standard deviation

$C T L$ control, $C T L+A P O$ control treated with apocynin, DM diabetes mellitus, $D M+A P O$ diabetes mellitus treated with apocynin, LVDD and LVSD left ventricular (LV) diastolic and systolic diameters, respectively, $B W$ body weight, PWT LV posterior wall thickness, $L A$ left atrial diameter, LVM LV mass

${ }^{*} p<0.05$ vs $C T L ; ; p<0.05$ vs CTL + APO

functional data are presented in Table 3. Consistent impairment of systolic function was observed in diabetic groups (EFS, EF, PWSV, and $\mathrm{S}^{\prime}$ were lower in both diabetic groups); apocynin did not change these variables. Isovolumic relaxation time was higher in diabetics than controls and unchanged by apocynin. Mitral E/A ratio was higher in DM + APO than DM.

Baseline LV papillary muscle data are shown in Table 4. Diabetic groups had impaired contractile (lower $+\mathrm{dT} /$ $\mathrm{dt}$ and higher TPT) and relaxation (lower - dT/dt) function. Apocynin did not change basal papillary muscle performance. After all positive inotropic stimulation, DT was lower in DM than CTL. However, in DM + APO, DT

Table 3 Echocardiographic left ventricular functional data

\begin{tabular}{lllll}
\hline & $\begin{array}{l}\text { CTL } \\
(\mathbf{n}=13)\end{array}$ & $\begin{array}{l}\text { CTL+ APO } \\
(\mathbf{n}=\mathbf{1 9})\end{array}$ & $\begin{array}{l}\text { DM } \\
(\mathbf{n}=\mathbf{1 7})\end{array}$ & $\begin{array}{l}\text { DM + APO } \\
(\mathbf{n}=\mathbf{1 6})\end{array}$ \\
\hline EFS (\%) & $53.3 \pm 4.90$ & $53.3 \pm 5.45$ & $49.0 \pm 5.19^{*}$ & $46.9 \pm 5.59^{\#}$ \\
$\mathrm{EF}$ & $0.90 \pm 0.03$ & $0.89 \pm 0.03$ & $0.86 \pm 0.04^{*}$ & $0.85 \pm 0.05^{\#}$ \\
$\mathrm{PWSV}$ & $38.1 \pm 3.84$ & $37.2 \pm 3.51$ & $27.9 \pm 2.21^{*}$ & $30.2 \pm 5.35^{\#}$ \\
$\quad(\mathrm{~mm} / \mathrm{s})$ & & & & \\
$\mathrm{S}^{\prime}(\mathrm{cm} / \mathrm{s})$ & $3.50(3.25-$ & $3.50(3.50-$ & $3.00(3.94-$ & $3.00(2.50-$ \\
& $3.56)$ & $3.75)$ & $3.00)^{*}$ & $3.00)^{\#}$ \\
Mitral E/A & $1.46 \pm 0.16$ & $1.55 \pm 0.28$ & $1.29 \pm 0.20$ & $1.47 \pm 0.30^{\text {ई }}$ \\
IVRT (ms) & $28.9 \pm 2.63$ & $30.1 \pm 3.12$ & $38.6 \pm 6.05^{*}$ & $38.6 \pm 4.56^{\#}$ \\
E/E' & $18.3 \pm 3.51$ & $18.8 \pm 3.40$ & $18.4 \pm 3.01$ & $19.7 \pm 3.86$ \\
\hline
\end{tabular}

Data are expressed as mean \pm standard deviation or median and 25 th and 75 th percentiles

$C T L$ control, $C T L+A P O$ control treated with apocynin, DM diabetes mellitus, $D M+A P O$ diabetes mellitus treated with apocynin, EFS endocardial fractional shortening, EF ejection fraction, PWSV posterior wall shortening velocity, $S^{\prime}$ tissue Doppler imaging of systolic velocity of the mitral annulus (average of septal and lateral wall), E/A ratio between early (E)-to-late (A) diastolic mitral inflow, IVRT isovolumic relaxation time, $E^{\prime}$ tissue Doppler imaging of early diastolic velocity of mitral annulus (average of septal and lateral wall)

${ }^{*} \mathrm{p}<0.05$ vs CTL; ${ }^{\#}$ < 0.05 vs CTL + APO; ${ }^{\S} \mathrm{p}<0.05$ vs DM 
Table 4 Basal left ventricular papillary muscle data

\begin{tabular}{cllll}
\hline & $\begin{array}{l}\text { CTL } \\
(\mathbf{n}=13)\end{array}$ & $\begin{array}{l}\text { CTL + APO } \\
(\mathbf{n}=13)\end{array}$ & $\begin{array}{l}\text { DM } \\
(\mathbf{n}=12)\end{array}$ & $\begin{array}{l}\text { DM + APO } \\
(\mathbf{n}=13)\end{array}$ \\
\hline $\begin{array}{l}\mathrm{DT}\left(\mathrm{g} / \mathrm{mm}^{2}\right) \\
+\mathrm{dT} / \mathrm{dt}(\mathrm{g} /\end{array}$ & $7.53 \pm 1.48$ & $7.67 \pm 1.20$ & $5.98 \pm 2.86$ & $7.23 \pm 1.82$ \\
$\mathrm{~mm} / \mathrm{s})$ & $79.9 \pm 15.4$ & $78.5 \pm 13.6$ & $52.5 \pm 25.5^{*}$ & $63.5 \pm 16.5^{\#}$ \\
$\mathrm{TPT}(\mathrm{ms})$ & $183 \pm 13$ & $194 \pm 17$ & $224 \pm 16^{*}$ & $230 \pm 13^{\#}$ \\
$-\mathrm{dT} / \mathrm{dt}(\mathrm{g} /$ & $32.0 \pm 6.17$ & $31.3 \pm 6.55$ & $20.7 \pm 8.11^{*}$ & $23.8 \pm 5.84^{\#}$ \\
$\left.\mathrm{~mm}^{2} / \mathrm{s}\right)$ & & & & \\
$\mathrm{RT}\left(\mathrm{g} / \mathrm{mm}^{2}\right)$ & $1.00 \pm 0.31$ & $0.86 \pm 0.38$ & $0.85 \pm 0.47$ & $0.79 \pm 0.25$ \\
\hline
\end{tabular}

Data are expressed as mean \pm standard deviation

$C T L$ control, $C T L+A P O$ control treated with apocynin, DM diabetes mellitus, $D M+A P O$ diabetes mellitus treated with apocynin, $D T$ peak of developed tension, $+d T / d t$ maximum rate of tension development, TPT time to peak tension, $-d T / d t$ maximum rate of tension decline, $R T$ resting tension

${ }^{*} \mathrm{p}<0.05$ vs CTL; ${ }^{\mathrm{p}}<0.05$ vs $\mathrm{CTL}+\mathrm{APO}$

values were between those in DM and CTL $+\mathrm{APO}$ and did not significantly differ from either group (Table 5).

Left ventricular myocyte diameters did not differ between groups. Myocardial interstitial collagen fraction was higher in DM than CTL (CTL 2.14 \pm 1.29 ; $\mathrm{CTL}+\mathrm{APO} 1.74 \pm 0.90 ; \mathrm{DM} 5.05 \pm 2.98 ; \mathrm{DM}+\mathrm{APO}$ $3.12 \pm 1.35 \%$; $<0.05$ DM vs CTL). In DM + APO, values for this parameter were between those in DM and $\mathrm{CTL}+\mathrm{APO}$ and did not significantly differ from either group.

Table 6 shows serum glucose levels and antioxidant enzyme activity. Glycaemia was higher in diabetic groups. Catalase was lower in DM than CTL. Superoxide dismutase and glutathione peroxidase were lower in $\mathrm{DM}$ and CTL + APO than CTL. In DM + APO, catalase was higher than DM and superoxide dismutase was higher than DM and CTL + APO. Myocardial $\mathrm{NADPH}$ oxidase activity did not differ between groups (Table 7).

Table 5 Peak of developed tension (DT, $\mathrm{g} / \mathrm{mm}^{2}$ ) of left ventricular papillary muscle following positive inotropic stimulation

\begin{tabular}{lllll}
\hline & $\begin{array}{l}\text { CTL } \\
(\mathbf{n}=13)\end{array}$ & $\begin{array}{l}\text { CTL+ APO } \\
(\mathbf{n}=13)\end{array}$ & $\begin{array}{l}\text { DM } \\
(\mathbf{n}=12)\end{array}$ & $\begin{array}{l}\text { DM + APO } \\
(\mathbf{n}=\mathbf{1 3})\end{array}$ \\
\hline PP30 & $9.47 \pm 2.36$ & $9.44 \pm 1.97$ & $6.73 \pm 3.23^{*}$ & $8.27 \pm 2.29$ \\
{$\left[\mathrm{Ca}^{2+}\right]_{0} 2.5 \mathrm{mM}$} & $8.61 \pm 2.14$ & $8.95 \pm 1.87$ & $6.28 \pm 2.94^{*}$ & $7.60 \pm 2.11$ \\
Iso $10^{-6} \mathrm{M}$ & $7.79 \pm 2.32$ & $7.86 \pm 1.63$ & $5.62 \pm 2.61^{*}$ & $6.54 \pm 2.06$ \\
\hline
\end{tabular}

Data are expressed as mean \pm standard deviation

$C T L$ control, $C T L+A P O$ control treated with apocynin, DM diabetes mellitus, $D M+A P O$ diabetes mellitus treated with apocynin, $P P 3030$-s post-rest contraction, $\left[\mathrm{Ca}^{2+}\right]_{0} 2.5 \mathrm{mM}$ extracellular calcium concentration, Iso $10^{-6} \mathrm{M}$ $\beta$-adrenergic agonist isoproterenol addition to the nutrient solution

${ }^{*} \mathrm{p}<0.05$ vs $\mathrm{CTL}$
Table 6 Glycemia and serum oxidative stress

\begin{tabular}{|c|c|c|c|c|}
\hline & $\begin{array}{l}\text { CTL } \\
(n=8)\end{array}$ & $\begin{array}{l}C T L+A P O \\
(n=8)\end{array}$ & $\begin{array}{l}\text { DM } \\
(n=8)\end{array}$ & $\begin{array}{l}\mathrm{DM}+\mathrm{APO} \\
(\mathrm{n}=8)\end{array}$ \\
\hline $\begin{array}{l}\text { Glycemia (mg/ } \\
\text { dL) }\end{array}$ & $100 \pm 22$ & $100 \pm 16$ & $599 \pm 5^{*}$ & $589 \pm 37^{\#}$ \\
\hline $\begin{array}{l}\text { Catalase } \\
\quad(\mu \mathrm{mol} / \mathrm{g})\end{array}$ & $4.21 \pm 1.10$ & $3.88 \pm 1.40$ & $1.08 \pm 0.58^{*}$ & $4.43 \pm 1.73^{\S}$ \\
\hline $\mathrm{SOD}(\mathrm{nmol} / \mathrm{mg})$ & $6.43 \pm 0.59$ & $5.65 \pm 0.56^{*}$ & $5.35 \pm 0.28^{*}$ & $6.67 \pm 0.80^{\# \S}$ \\
\hline $\begin{array}{l}\text { GSH-Px (nmol/ } \\
\text { mg) }\end{array}$ & $42.2 \pm 7.70$ & $25.0 \pm 4.41^{*}$ & $30.9 \pm 3.43^{*}$ & $29.5 \pm 3.44$ \\
\hline
\end{tabular}

Data are expressed as mean \pm standard deviation

$C T L$ control, $C T L+A P O$ control treated with apocynin, DM diabetes mellitus, $D M+A P O$ diabetes mellitus treated with apocynin, $S O D$ superoxide dismutase, $G S H-P x$ glutathione peroxidase

${ }^{*} \mathrm{p}<0.05$ vs CTL; ${ }^{\mathrm{p}}<0.05$ vs CTL $+\mathrm{APO} ;{ }^{\S} \mathrm{p}<0.05$ vs DM

Table 7 Myocardial NADPH oxidase activity

\begin{tabular}{lllll}
\hline & $\begin{array}{l}\text { CTL } \\
(\mathbf{n = 8})\end{array}$ & $\begin{array}{l}\text { CTL + APO } \\
(\mathbf{n = 8})\end{array}$ & $\begin{array}{l}\text { DM } \\
(\mathbf{n = 8})\end{array}$ & $\begin{array}{l}\text { DM + APO } \\
(\mathbf{n = 8})\end{array}$ \\
\hline $\mathrm{EOH}(\mathrm{nM})$ & $38.1 \pm 12.9$ & $38.6 \pm 11.1$ & $36.0 \pm 4.26$ & $29.8 \pm 6.38$ \\
Ethidium (nM) & $103 \pm 76$ & $111 \pm 77$ & $102 \pm 46$ & $109 \pm 51$ \\
\hline
\end{tabular}

Data are expressed as mean \pm standard deviation. NADPH oxidase activity was evaluated in membrane-enriched cellular fraction by quantifying two dihydroethidium oxidation-derived fluorescent compounds, 2-hydroxyethidium $(\mathrm{EOH})$ and ethidium

$C T L$ control, $C T L+A P O$ control treated with apocynin, DM diabetes mellitus, $D M+A P O$ diabetes mellitus treated with apocynin

$\mathrm{p}=\mathrm{ns}$

\section{Discussion}

Apocynin has been widely evaluated in experimental research as an antioxidant agent [17-19]. In literature several apocynin dosages have been used, ranging from $4 \mathrm{mg} / \mathrm{kg} /$ day [49] to $100 \mathrm{mg} / \mathrm{kg} /$ day [50]. In our study, we administered $16 \mathrm{mg} / \mathrm{kg} /$ day, a dosage usually reported in rodents $[51,52]$. Streptozotocin has often been used to induce type 1 diabetes in rodents $[28,53]$. As expected, diabetic rats presented higher glycemia levels and lower body weight than controls [26, 27, 54]. Apocynin did not attenuate hyperglycemia, body weight loss or blood pressure increase in diabetic groups.

Echocardiography showed changes compatible with diabetic cardiomyopathy $[55,56]$, characterized by dilation of the left chambers with systolic and diastolic dysfunction. Papillary muscle preparations are useful for evaluating myocardial function without influences from ventricular chamber geometry and cardiac load which can modulate in vivo cardiac performance. At baseline, diabetic groups showed impaired contraction and relaxation function, as observed in our previous studies $[26,28]$. As systolic blood pressure was slightly higher in diabetic groups, we could not rule out some influence 
from increased blood pressure on impaired ventricular function in diabetic rats. Therefore, myocardial function evaluation using papillary muscle preparations was important to reinforce the fact that systolic and diastolic function was depressed in diabetic rats.

Apocynin did not change cardiac structures or myocardial and ventricular function in the normoglycemic rats. Apocynin did increase E/A ratio in diabetic rats suggesting attenuation of diastolic dysfunction. In the papillary muscle preparations, developed tension was lower in DM than CTL after all positive inotropic stimulation. However, in DM + APO, values for developed tension were between those of CTL + APO and DM and did not significantly differ from either group. Therefore, the results from myocardial and ventricular functional evaluation suggest that apocynin slightly attenuated systolic and diastolic dysfunction in diabetic rats. Attenuation in myocardial interstitial fibrosis by apocynin in $\mathrm{DM}+\mathrm{APO}$ may have contributed to these results. In fact, in other experimental model, such as the spontaneously hypertensive rat, development of myocardial fibrosis has been associated with impaired contractile function and heart failure development [57].

Unexpectedly, NADPH oxidase activity did not differ between groups. Increased NADPH oxidase activity in diabetic rat myocardium has previously been reported [13, 58-61]. These divergent results may have occurred due to different animal and experimental models, and NADPH oxidase activity analytical technique [59-61].

Reactive oxygen species can be neutralized by endogenous antioxidant systems that include GSH-Px, SOD, and catalase antioxidant enzymes. Despite no differences in NADPH oxidase activity, systemic antioxidant enzymes were modulated by apocynin and diabetes. Catalase, SOD, and GSH-Px activity was reduced in the DM group. The influence of apocynin differed between control and diabetic rats. Apocynin reduced SOD and GSH-Px activity in control rats, and restored catalase and SOD activity in diabetic rats. We have previously observed that apocynin reduces myocardial GSH-Px activity in hypertensive rats [20]. Apocynin-induced normalization of SOD activity was recently reported in diabetic rabbits [25]. Reactive oxygen species generation intensity modulates the response to oxidative stress. While low concentrations of reactive oxygen species stimulate antioxidant enzymes, high concentrations inhibit enzymatic activity leading to cellular damage [62]. Our results suggest that apocynin had a beneficial effect on diabetic rats by restoring SOD and catalase activity.

Apocynin (4-hydroxy-3-methoxyacetophenone) is a methoxy-substituted catechol derived from the medicinal herb P. kurroa [16]. Its antioxidant effects have been evaluated in several experimental studies, mostly as a
NADPH oxidase inhibitor [17, 23]. However, this property has been put in check since apocynin failed to inhibit NADPH oxidase in cell culture; apocynin actually acted as a reactive oxygen species scavenger or a pro-oxidant agent $[19,63,64]$. Apocynin can also prevent NF-kB activation [24] and modulate nitric oxide-dependent pathways [65]. In several heart failure models, apocynin attenuated myocardial oxidative stress, apoptosis, hypertrophy, fibrosis, and diastolic dysfunction [11, 24, 66, 67].

However, only a few authors have examined the effects of apocynin on diabetic cardiomyopathy [13, 15, 25]. In accordance with our results, apocynin attenuated ventricular and myocardial dysfunction in diabetic mice $[15$, 49 ] and decreased reactive oxygen species production and apoptosis in the heart [13]. In diabetic mice [13, 15] and rabbits [25], apocynin also inhibited NADPH oxidase activity, which was not observed in our study. The conflicting result concerning these previous studies is probably related to the different animal species being evaluated. To the best of our knowledge, this is the first study to evaluate the cardiac effects of apocynin in diabetic rats. In summary, we showed that apocynin provided a mild improvement in ventricular diastolic function and myocardial contractile function and restored systemic SOD and catalase antioxidant enzyme activity. Further studies are needed to improve understanding of the influence apocynin has on the pathophysiology of diabetic cardiomyopathy.

\section{Conclusion}

Apocynin restores serum antioxidant enzyme activity despite unchanged myocardial NADPH oxidase activity in diabetic rats. This study reinforces the potential beneficial influence of antioxidants in diabetic cardiomyopathy.

\section{Abbreviations}

APO: apocynin; BW: body weights; $\left[\mathrm{Ca}^{2+}\right]^{0}$ : extracellular $\mathrm{Ca}^{2+}$ concentration; DHE: dihydroethidium; DM: diabetes mellitus; DT: peak of developed tension; $+d T / d t$ : maximum rate of tension development; $-d T / d t$ : maximum rate of tension decline; $\mathrm{EOH}$ : 2-hydroxyethidium; E wave: early diastolic mitral inflow velocity; E/A: ratio between early (E)-to-late (A) diastolic mitral inflow; EF: ejection fraction; EFS: endocardial fractional shortening; GSH-Px: glutathione peroxidase; SOD: superoxide dismutase; IVRT: isovolumetric relaxation time; $L A$ : left atrium; $L_{\text {max }}$ : peak of the length-tension curve; LV: left ventricle; LVDD: left ventricle diastolic diameter; LVSD: left ventricle systolic diameter; $\mathrm{NADPH}$ : nicotinamide adenine dinucleotide phosphate; PWSV: posterior wall shortening velocity; PWT: left ventricle diastolic posterior wall thickness; ROS: reactive oxygen species; $R T$ : resting tension; $S^{\prime}$ : mitral annulus systolic velocity; SAP: systolic arterial pressure; TDI: tissue Doppler imaging; TPT: time to peak tension.

\section{Authors' contributions}

$R G, C G$ and $K O$ contributed to study conception and design, acquisition of data, analysis and interpretation of data, and manuscript writing; CMR, NPX, DHSC, AAHF, MDMC, GNG, IDC, and ACC contributed to data collection, DCF and FRL contributed to data collection and analysis, MPO contributed to manuscript writing. All authors read and approved the final manuscript. 


\begin{abstract}
Author details
${ }^{1}$ Department of Internal Medicine, Botucatu Medical School, Sao Paulo State University, UNESP, Botucatu, SP, Brazil. ${ }^{2}$ Sagrado Coração University, Bauru, SP, Brazil. ${ }^{3}$ Institute of Biosciences, Sao Paulo State University (UNESP), Botucatu, SP, Brazil. ${ }^{4}$ Department of Cardiopneumology, Medical School, Sao Paulo University, USP, São Paulo, Brazil. ${ }^{5}$ Departamento de Clinica Medica, Faculdade de Medicina de Botucatu, Sao Paulo State University, UNESP, Rubiao Junior, S/N, Botucatu, SP CEP 18618-687, Brazil.
\end{abstract}

\section{Acknowledgements}

The authors are grateful to Jose Carlos Georgette for his technical assistance and Colin Edward Knaggs for English editing.

\section{Competing interests}

The authors declare that they have no competing interests.

\section{Availability of data and materials}

All data generated or analyzed during this study are included in this published article.

\section{Consent for publication}

All authors have consent for manuscript publication.

\section{Ethics approval and consent to participate}

All experiments and procedures were approved by the Ethics Committee of Botucatu Medical School, Sao Paulo State University, UNESP, Botucatu, SP, Brazil.

\section{Funding}

Financial support was provided by FAPESP (Proc. n. 2011/04528-4 and 2015/17539-5), CNPq (Proc. n. 306770/2015-6, 480829/2013-6, and 308674/2015-4), CAPES, and PROPe, UNESP. The funding sources had no involvement in study design; data collection, analysis and interpretation; or report writing.

\section{Publisher's Note}

Springer Nature remains neutral with regard to jurisdictional claims in published maps and institutional affiliations.

Received: 2 November 2017 Accepted: 26 December 2017

Published online: 17 January 2018

\section{References}

1. Jia G, DeMarco VG, Sowers JR. Insulin resistance and hyperinsulinaemia in diabetic cardiomyopathy. Nat Rev Endocrinol. 2016;12:144-53.

2. American Diabetes Association. Standards of medical care in diabetes-2017. Abridged for primary care providers. Clin Diabetes. 2017:35:5-26.

3. Holscher ME, Bode C, Bugger H. Diabetic cardiomyopathy: does the type of diabetes matter? Int J Mol Sci. 2016;17:E2136.

4. Lorenzo-Almorós A, Tunón J, Orejas M, Cortés M, Egido J, Lorenzo Ó. Diagnostic approaches for diabetic cardiomyopathy. Cardiovasc Diabetol. 2017;16:28.

5. Asghar O, Al-Sunni A, Khavandi K, Khavandi A, Withers S, Greenstein A, Heagerty AM, Malik RA. Diabetic cardiomyopathy. Clin Sci. 2009;116:741-60.

6. Lew JK, Pearson JT, Schwenke DO, Katare R. Exercise mediated protection of diabetic heart through modulation of microRNA mediated molecular pathways. Cardiovasc Diabetol. 2017;16:10.

7. Aydemir-Koksoy A, Bilginoglu A, Sariahmetoglu M, Schulz R, Turan B. Antioxidant treatment protects diabetic rats from cardiac dysfunction by preserving contractile protein targets of oxidative stress. J Nutr Biochem. 2010;21:827-33.

8. Liu Q, Wang S, Cai L. Diabetic cardiomyopathy and its mechanisms: role of oxidative stress and damage. J Diabetes Investig. 2014;5:623-34.

9. Li JM, Gall NP, Grieve M, Shah AM. Activation of NADPH oxidase during progression of cardiac hypertrophy to failure. Hypertension. 2002:40:477-84.
10. Murdoch CE, Zhang M, Cave AC, Shah AM. NADPH oxidase-dependent redox signalling in cardiac hypertrophy, remodelling and failure. Cardiovasc Res. 2006;71:208-15.

11. Liu JJ, Lu Y, Ping NN, Li X, Lin YX, Li CF. Apocynin ameliorates pressure overload-induced cardiac remodeling by inhibiting oxidative stress and apoptosis. Physiol Res. 2017;66:741-52.

12. Privratsky JR, Wold LE, Sowers JR, Quinn MT, Ren J. AT1 blockade prevents glucose-induced cardiac dysfunction in ventricular myocytes: role of the AT1 receptor and NADPH oxidase. Hypertension. 2003;42:206-12.

13. Shen E, Li Y, Li Y, Shan L, Zhu H, Feng Q, Arnold JM, Peng T. Rac1 is required for cardiomyocyte apoptosis during hyperglycemia. Diabetes. 2009;58:2386-95

14. Thandavarayan RA, Watanabe K, Ma M, Gurusamy N, Veeraveedu PT, Konishi T, Zhang S, Muslin AJ, Kodama M, Aizawa Y. Dominant-negative p38alpha mitogen-activated protein kinase prevents cardiac apoptosis and remodeling after streptozotocin-induced diabetes mellitus. Am J Physiol Heart Circ Physiol. 2009;297:H911-9.

15. Li J, Shu H, Shen E, Wan L, Arnold JM, Peng T. Deficiency of rac1 blocks NADPH oxidase activation, inhibits endoplasmic reticulum stress and reduces myocardial remodeling in type 1 diabetic mice. Diabetes. 2010;59:2033-42.

16. Van den Worm E, Beukelman CJ, Van den Berg AJ, Kroes BH, Labadie RP, Van Dijk H. Effects of methoxylation of apocynin and analogs on the inhibition of reactive oxygen species production by stimulated human neutrophils. Eur J Pharmacol. 2001:433:225-30.

17. Trevelin SC, Dos Santos CX, Ferreira RG, de Sá Lima L, Silva RL, Scavone C, Curi R, Alves-Filho JC, Cunha TM, Roxo-Júnior P, et al. Apocynin and Nox2 regulate NF-kB by modifying thioredoxin-1 redox-state. Sci Rep. 2016;6:34581.

18. Altenhofer S, Radermacher KA, Kleikers PW, Wingler K, Schmidt HH. Evolution of NADPH oxidase inhibitors: selectivity and mechanisms for target engagement. Antioxid Redox Signal. 2015;23:406-27.

19. Heumüller S, Wind S, Barbosa-Sicard E, Schmidt HH, Busse R, Schröder K, Brandes RP. Apocynin is not an inhibitor of vascular NADPH oxidases but an antioxidant. Hypertension. 2008;51:211-7.

20. Rosa CM, Gimenes R, Campos DH, Guirado GN, Gimenes C, Fernandes AA Cicogna AC, Queiroz RM, Falcão-Pires I, Miranda-Silva D, et al. Apocynin influence on oxidative stress and cardiac remodeling of spontaneously hypertensive rats with diabetes mellitus. Cardiovasc Diabetol. 2016:15:126.

21. Liu ZH, Dai DP, Ding FH, Pan WQ, Fang YH, Zhang Q, Li M, Yang P, Wang $X Q$, Shen $Y$, et al. Association of serum HMGB2 level with MACE at 1 mo of myocardial infarction: aggravation of myocardial ischemic injury in rats by HMGB2 via ROS. Am J Physiol Heart Circ Physiol. 2017:312:H422-36.

22. Uysal A, Sahna E, Ozguler IM, Burma O, Ilhan N. Effects of apocynin, an NADPH oxidase inhibitor, on levels of ADMA, MPO, iNOS and TLR4 induced by myocardial ischemia reperfusion. Perfusion. 2015;30:472-7.

23. Gonzalez DR, Treuer AV, Lamirault G, Mayo V, Cao Y, Dulce RA, Hare JM. NADPH oxidase-2 inhibition restores contractility and intracellular calcium handling and reduces arrhythmogenicity in dystrophic cardiomyopathy. Am J Physiol Heart Circ Physiol. 2014;307:H710-21.

24. Zhang L, Li F, Zhi G, Zhang B, Chen YD. NADPH oxidase contributes to the left ventricular dysfunction induced by sinoaortic denervation in rats. Free Radic Res. 2015;49:57-66.

25. Qiu J, Zhao J, Li J, Liang X, Yang Y, Zhang Z, Zhang X, Fu H, Korantzopoulos $P$, Tse $G$, et al. Apocynin attenuates left ventricular remodeling in diabetic rabbits. Oncotarget. 2017:8:38482-90.

26. Gimenes C, Gimenes R, Rosa CM, Xavier NP, Campos DHS, Fernandes AAH, Cezar MDM, Guirado GN, Cicogna AC, Takamoto AHR, et al. Low intensity physical exercise attenuates cardiac remodeling and myocardial oxidative stress and dysfunction in diabetic rats. J Diabetes Res. 2015:ID 457848.

27. Guimaraes JF, Muzio BP, Rosa CM, Nascimento AF, Sugizaki MM, Fernandes AA, Cicogna AC, Padovani CR, Okoshi MP, Okoshi K. Rutin administration attenuates myocardial dysfunction in diabetic rats. Cardiovasc Diabetol. 2015;14:90.

28. Rosa CM, Xavier NP, Campos DH, Fernandes AA, Cezar MD, Martinez PF, Cicogna AC, Gimenes C, Gimenes R, Okoshi MP, et al. Diabetes mellitus activated fetal gene program and intensifies cardiac remodeling and oxidative stress in aged spontaneously hypertensive rats. Cardiovasc Diabetol. 2013;12:152.

29. Lu J, Pontre B, Pickup S, Choong SY, Li M, Xu H, Gamble GD, Phillips AR, Cowan BR, Young AA, et al. Treatment with a copper-selective chelator 
causes substantive improvement in cardiac function of diabetic rats with left-ventricular impairment. Cardiovasc Diabetol. 2013;12:28.

30. Cezar MD, Damatto RL, Martinez PF, Lima AR, Campos DH, Rosa CM, Guizoni DM, Bonomo C, Cicogna AC, Gimenes R, et al. Aldosterone blockade reduces mortality without changing cardiac remodeling in spontaneously hypertensive rats. Cell Physiol Biochem. 2013;32:1275-87.

31. Martinez PF, Okoshi K, Zornoff LA, Carvalho RF, Oliveira Junior SA, Lima AR, Campos DH, Damatto RL, Nogueira CR, Dal Pai-Silva M, et al. Chronic heart failure-induced skeletal muscle atrophy, necrosis, and myogenic regulatory factors changes. Med Sci Monit. 2010;16:374-83.

32. Martinez PF, Bonomo C, Guizoni DM, Junior SA, Damatto RL, Cezar MD, Lima AR, Pagan LU, Seiva FR, Bueno RT, et al. Modulation of MAPK and NF-kB signaling pathways by antioxidant therapy in skeletal muscle of heart failure rats. Cell Physiol Biochem. 2016;39:371-84.

33. Lima AR, Martinez PF, Damatto RL, Cezar MD, Guizoni DM, Bonomo C, Oliveira SAJ, Dal-Pai Silva M, Zornoff LA, Okoshi K, et al. Heart failureinduced diaphragm myopathy. Cell Physiol Biochem. 2014;34:333-45.

34. Oliveira Junior SA, Dal Pai-Silva M, Martinez PF, Lima-Leopoldo AP, Campos DH, Leopoldo AS, Okoshi MP, Okoshi K, Padovani CR, Cicogna AC. Diet-induced obesity causes metabolic, endocrine and cardiac alterations in spontaneously hypertensive rats. Med Sci Monit. 2010;16:BR367-73.

35. Lang RM, Badano LP, Mor-Avi V, Afilalo J, Armstrong A, Ernande L, Flachskampf FA, Foster E, Goldstein SA, Kuznetsova T, et al. Recommendations for cardiac chamber quantification by echocardiography in adults: an update from the American Society of Echocardiography and The European Association of Cardiovascular Imaging. Eur Heart J Cardiovasc Imaging. 2015;16:233-70

36. Pagan LU, Damatto RL, Cezar MD, Lima AR, Bonomo C, Campos DH, Gomes MJ, Martinez PF, Oliveira SAJ, Gimenes R, et al. Long-term low intensity physical exercise attenuates heart failure development in aging spontaneously hypertensive rats. Cell Physiol Biochem. 2015;36:61-74.

37. Gomes MJ, Martinez PF, Campos DHS, Pagan LU, Bonomo C, Lima AR, Damatto RL, Cezar MD, Damatto FC, Rosa CM, et al. Beneficial effects of physical exercise on functional capacity and skeletal muscle oxidative stress in rats with aortic stenosis-induced heart failure. Oxid Med Cell Longev. 2016;2016:8695716.

38. Okoshi K, Fioretto JR, Okoshi MP, Cicogna AC, Aragon FF, Matsubara LS, Matsubara BB. Food restriction induces in vivo ventricular dysfunction in spontaneously hypertensive rats without impairment of in vitro myocardial contractility. Braz J Med Biol Res. 2004;37:607-13.

39. Sugizaki MM, Carvalho RF, Aragon FF, Padovani CR, Okoshi K, Okoshi MP, Zanati SG, Pai-Silva MD, Novelli EL, Cicogna AC. Myocardial dysfunction induced by food restriction is related to morphological damage in normotensive middle-aged rats. J Biomed Sci. 2005;12:641-9.

40. Cicogna AC, Padovani CR, Okoshi K, Aragon FF, Okoshi MP. Myocardial function during chronic food restriction in isolated hypertrophied cardiac muscle. Am J Med Sci. 2000;320:244-8.

41. Okoshi MP, Cezar MD, lyomasa RM, Silva MB, Costa LC, Martinez PF, Campos DH, Damatto RL, Minicucci MF, Cicogna AC, et al. Effects of early aldosterone antagonism on cardiac remodeling in rats with aortic stenosis-induced pressure overload. Int J Cardiol. 2016;222:569-75.

42. Cezar MD, Damatto RL, Pagan LU, Lima AR, Martinez PF, Bonomo C, Rosa CM, Campos DH, Cicogna AC, Gomes MJ, et al. Early spironolactone treatment attenuates heart failure development by improving myocardial function and reducing fibrosis in spontaneously hypertensive rats. Cell Physiol Biochem. 2015;36:1453-66.

43. Damatto RL, Martinez PF, Lima AR, Cezar MD, Campos DH, Oliveira SAJ, Guizoni DM, Bonomo C, Nakatani BT, Dal Pai Silva M, et al. Heart failureinduced skeletal myopathy in spontaneously hypertensive rats. Int J Cardiol. 2013;167:698-703.

44. Damatto RL, Lima AR, Martinez PF, Cezar MD, Okoshi K, Okoshi MP. Myocardial myostatin in spontaneously hypertensive rats with heart failure. Int J Cardiol. 2016;215:384-7.

45. Matsubara LS, Matsubara BB, Okoshi MP, Franco M, Cicogna AC. Myocardial fibrosis rather than hypertrophy induces diastolic dysfunction in renovascular hypertensive rats. Can J Physiol Pharmacol. 1997;75:1328-34.

46. Fernandes DC, Wosniak J, Pescatore LA, Bertoline MA, Liberman M, Laurindo FRM, Santos CXC. Analysis of DHE-derived oxidation products by HPLC in the assessment of superoxide production and NADPH oxidase activity in vascular systems. Am J Physiol Cell Physiol. 2007;292:C413-22.
47. Laurindo FRM, Fernandes DC, Santos CXC. Assessment of superoxide production and NADPH oxidase activity by HPLC analysis of dihydroethidium oxidation products. Methods Enzymol. 2008;441:237-60.

48. Oliveira-Junior SA, Martinez PF, Fan WYC, Nakatani BT, Pagan LU, Padovani CR, Cicogna AC, Okoshi MP, Okoshi K. Association between echocardiographic structural parameters and body weight in Wistar rats. Oncotarget. 2017:8:26100-5.

49. Roe ND, Thomas DP, Ren J. Inhibition of NADPH oxidase alleviates experimental diabetes-induced myocardial contractile dysfunction. Diabetes Obes Metab. 2011;13:465-73.

50. Shi XY, Hou FF, Niu HX, Wang GB, Xie D, Guo ZJ, Zhou ZM, Yang F, Tian $J W$, Zhang X. Advanced oxidation protein products promote inflammation in diabetic kidney through activation of renal nicotinamide adenine dinucleotide phosphate oxidase. Endocrinology. 2008;149:1829-39.

51. Asaba K, Tojo A, Onozato ML, Goto A, Quinn MT, Fujita T, Wilcox CS. Effects of NADPH oxidase inhibitor in diabetic nephropathy. Kidney Int. 2005;67:1890.

52. Olukman M, Orhan CE, Celenk FG, Ulker S. Apocynin restores endothelial dysfunction in streptozotocin diabetic rats through regulation of nitric oxide synthase and NADPH oxidase expressions. J Diabetes Complicat. 2010;24:415-23.

53. Fernandes AA, Novelli EL, Okoshi K, Okoshi MP, Di Muzio BP, Guimaraes JF, Fernandes A Jr. Influence of rutin treatment on biochemical alterations in experimental diabetes. Biomed Pharmacother. 2010;64:214-9.

54. Savi M, Bocchi L, Mena P, Dall'Asta M, Crozier A, Brighenti F, Stilli D, Del Rio D. In vivo administration of urolithin $A$ and $B$ prevents the occurrence of cardiac dysfunction in streptozotocin-induced diabetic rats. Cardiovasc Diabetol. 2017;16:80.

55. Habibi J, Aroor AR, Sowers JR, Jia G, Hayden MR, Garro M, Barron B, Mayoux E, Rector RS, Whaley-Connell A, et al. Sodium glucose transporter 2 (SGLT2) inhibition with empagliflozin improves cardiac diastolic function in a female rodent model of diabetes. Cardiovasc Diabetol. 2017;16:9.

56. Cheng YS, Dai DZ, Dai Y, Zhu DD, Liu BC. Exogenous hydrogen sulphide ameliorates diabetic cardiomyopathy in rats by reversing disordered calcium-handling system in sarcoplasmic reticulum. J Pharm Pharmacol. 2016;68:379-88.

57. Brooks WW, Bing OHL, Boluyt MO, Malhotra A, Morgan JP, Satoh N, Colucci WS, Conrad CH. Altered inotropic responsiveness and gene expression of hypertrophied myocardium with captopril. Hypertension. 2000;35:1203-9.

58. Prakoso D, De Blasio MJ, Qin C, Rosli S, Kiriazis H, Qian H, Du XJ, Weeks KL, Gregorevic P, McMullen JR, et al. Phosphoinositide 3-kinase (p110a) gene delivery limits diabetes-induced cardiac NADPH oxidase and cardiomyopathy in a mouse model with established diastolic dysfunction. Clin Sci. 2017;131:1345-60.

59. Adebiyi OA, Adebiyi OO, Owira PM. Naringin reduces hyperglycemiainduced cardiac fibrosis by relieving oxidative stress. PLOS ONE. 2016;11:e0149890.

60. Zheng H, Pu SY, Fan XF, Li XS, Zhang Y, Yuan J, Zhang YF, Yang JL. Treatment with angiotensin-(1-9) alleviates the cardiomyopathy in streptozotocin-induced diabetic rats. Biochem Pharmacol. 2015;95:38-45.

61. Inoue T, Inoguchi T, Sonoda N, Hendarto H, Makimura H, Sasaki S, Yokomizo H, Fujimura Y, Miura D, Takayanagi R. GLP-1 analog liraglutide protects against cardiac steatosis, oxidative stress and apoptosis in streptozotocin-induced diabetic rats. Atherosclerosis. 2015;240:250-9.

62. Radak Z, Chung HY, Goto S. Exercise and hormesis: oxidative stressrelated adaptation for successful aging. Biogerontology. 2005;6:71-5.

63. Castor LR, Locatelli KA, Ximenes VF. Pro-oxidant activity of apocynin radical. Free Radic Biol Med. 2010;48:1636-43.

64. Riganti C, Costamagna C, Bosia A, Ghigo D. The NADPH oxidase inhibitor apocynin (acetovanillone) induces oxidative stress. Toxicol Appl Pharmacol. 2006;212:179-87.

65. Riganti C, Costamagna C, Doublier S, Miraglia E, Polimeni M, Bosia A, Ghigo D. The NADPH oxidase inhibitor apocynin induces nitric oxide synthesis via oxidative stress. Toxicol Appl Pharmacol. 2008;228:277-85.

66. Li YQ, Li XB, Guo SJ, Chu SL, Gao PJ, Zhu DL, Niu WQ, Jia N. Apocynin attenuates oxidative stress and cardiac fibrosis in angiotensin II-induced cardiac diastolic dysfunction in mice. Acta Pharmacol Sin. 2013;34:352-9.

67. Liu J, Zhou J, An W, Lin Y, Yang Y, Zang W. Apocynin attenuates pressure overload-induced cardiac hypertrophy in rats by reducing levels of reactive oxygen species. Can J Physiol Pharmacol. 2010;88:745-52. 